\title{
Elevated alkalinity and sulfate adversely affect the aquatic macrophyte Lobelia dortmanna
}

\author{
Cristina Pulido • Danny J. H. Keijsers • \\ Esther C. H. E. T. Lucassen • Ole Pedersen • \\ Jan G. M. Roelofs
}

Received: 24 October 2011/Accepted: 2 May 2012/Published online: 27 May 2012

(C) The Author(s) 2012. This article is published with open access at Springerlink.com

\begin{abstract}
The increase in alkalinity and $\mathrm{SO}_{4}{ }^{2-}$ in softwater lakes can negatively affect pristine isoetid population because the increase in alkalinity and $\mathrm{SO}_{4}{ }^{2-}$ can stimulate sediment mineralization and consequently cause anoxia. The consequences of increased sediment mineralization depend on the ability of isoetids such as Lobelia dortmanna to oxidize the rhizosphere via radial $\mathrm{O}_{2}$ loss. To study how alkalinity and $\mathrm{SO}_{4}{ }^{2-}$ affect the isoetid L. dortmanna, and if negative effects could be alleviated by neighboring plants, three densities of L. dortmanna
\end{abstract}

Handling Editor: Liesbeth Bakker.

C. Pulido ( $\square)$

Centre d'Estudis Avançats de Blanes, CEAB-CSIC,

Ac. Cala St. Francesc 14, 17300 Blanes, Spain

e-mail: cpulido@ceab.csic.es

\section{J. H. Keijsers · J. G. M. Roelofs}

Department of Aquatic Ecology and Environmental

Biology, Institute for Water and Wetland Research,

Radboud University Nijmegen, Heyendaalseweg 135,

6525 AJ Nijmegen, The Netherlands

E. C. H. E. T. Lucassen

B-WARE Research Centre, Radboud University

Nijmegen, Toernooiveld 1, 6525 ED Nijmegen,

The Netherlands

\section{O. Pedersen}

Freshwater Biological Laboratory,

Department of Biology, University of Copenhagen,

Helsingørsgade 51, 3400 Hillerød, Denmark
("Low" = 64 plants $\mathrm{m}^{-2}$, "Medium" $=256$ plants $\mathrm{m}^{-2}$ and "High" = 1,024 plants $\mathrm{m}^{-2}$ ) were exposed to elevated alkalinity in the water column, or a combination of both elevated alkalinity and $\mathrm{SO}_{4}{ }^{2-}$, and compared to a control situation. The combination of $\mathrm{SO}_{4}{ }^{2-}$ and alkalinity significantly increased mortality, lowered areal biomass and reduced actual photosynthetic efficiency. Plant density did not significantly alleviate the negative effects caused by $\mathrm{SO}_{4}{ }^{2-}$ and alkalinity. However, actual photosynthetic efficiency was significantly positively correlated to redox potential in the sediment, indicating a positive relationship between plant performance and sediment oxidation. The negative effects on $L$. dortmanna were probably caused by long periods of tissue anoxia by itself or in combination with $\mathrm{H}_{2} \mathrm{~S}$ intrusion. Therefore, increase in both $\mathrm{SO}_{4}{ }^{2-}$ and alkalinity surface water can dramatically affect $L$. dortmanna populations, causing reduction or even disappearance of this icon species.

Keywords Isoetid $\cdot$ Redox potential $\cdot$ Sulfide . Softwater lake - Lobelia dortmanna .

Photosynthetic efficiency

\section{Introduction}

Softwater lakes have low surface water alkalinity $(<1 \mathrm{mM})$ and are naturally inhabited by slow-growing aquatic macrophytes called isoetids that are adapted to carbon and nutrient-limited systems (Arts 2002; 
Murphy 2002). Increasing alkalinity (alkalinization) above the low natural levels is among the main causes of degradation of the vegetation in softwater lakes (Arts 2002). Alkalinization happens by direct lime application used as a restoration measure to revert acidification (Brandrud 2002), by hydrological changes such as the introduction of alkaline water (Smolders and Roelofs 1995) or internally due to inlake processes such as the reduction in $\mathrm{SO}_{4}{ }^{2-}, \mathrm{NO}_{3}{ }^{-}$ or $\mathrm{Fe}$ in sediment mineralization processes (Psenner 1988; Smolders et al. 2006). Alkalinization can cause a shift in the vegetation from plant species characteristic of softwater (isoetids) to species characteristic of buffered conditions (elodeids, and other hard-water macrophytes) (Arts 2002). Elodeids benefit from the higher inorganic carbon availability and are fastgrowing, tall and ramifying plants that eventually overgrow the smaller slow-growing isoetids (Roelofs et al. 1994; Brandrud 2002; Lucassen et al. 2009; Spierenburg et al. 2009; 2010).

In addition to alkalinization, $\mathrm{SO}_{4}{ }^{2-}$ has also been reported to increase above the naturally low levels as a consequence of burning of fossil fuels. However, high $\mathrm{SO}_{4}{ }^{2-}$ concentrations alone do not seem to impact the natural vegetation as concentrations above $1 \mathrm{mM}$ have been reported in pristine isoetid lakes (Roelofs 1983). In contrast, it has been observed that the combined high $\mathrm{SO}_{4}{ }^{2-}$ and alkalinity result in regression or even total disappearance of isoetids (Brouwer et al. 1999). The negative effects produced by the combination of high $\mathrm{SO}_{4}{ }^{2-}$ and alkalinity seem to be linked to sediment mineralization processes (Brouwer et al. 1999). In anoxic sediments, mineralization is stimulated by $\mathrm{SO}_{4}{ }^{2-}$, which acts as an alternative electron acceptor to $\mathrm{O}_{2}$ (Ponnamperuma 1984; Laanbroek 1990), and by alkalinity, which neutralizes decayinhibiting acids and thus creates a more suitable environment for decomposer organisms (Traaen 1980; Kok and Van der Velde 1991). Increasing sediment mineralization leads to higher sediment $\mathrm{O}_{2}$ demand and results in reduced conditions. Although isoetids can resist short periods of tissue anoxia (Møller and Sand-Jensen 2011), long periods of tissue hypoxia and/or anoxia may decrease vascular translocation (Sorrell 2004), photosynthetic efficiency and plant growth (Pulido and Borum 2010) and can even cause mortality of sensitive aquatic macrophytes (SandJensen et al. 2005a; Raun et al. 2010). Moreover, under reduced conditions, $\mathrm{SO}_{4}{ }^{2-}$ is converted to sulfide which is known to be highly phytotoxic (Koch and Mendelssohn 1989; Goodman et al. 1995; Holmer and Bondgaard 2001; Geurts et al. 2009).

On the other hand, elevated sediment mineralization can also benefit the isoetid vegetation if the plants are able to maintain the rhizosphere oxidized (Pulido and Borum 2010; Pulido et al. 2011). Isoetids have a high radial $\mathrm{O}_{2}$ loss across the entire root system (SandJensen et al. 1982; Pedersen et al. 1995), and as a result, the rhizosphere is often permanently oxic, and problems with reduced phytotoxins are thus prevented (Holmer et al. 1998; Pedersen et al. 2004). Under such conditions with an oxic rhizosphere, the increased production of $\mathrm{CO}_{2}$, linked to sediment mineralization (Laanbroek 1990; Mattson and Likens 1993), can stimulate the underwater photosynthesis (Søndergaard and Sand-Jensen 1979; Roelofs et al. 1984; Pedersen et al. 1995) and growth of the isoetids (Madsen et al. 2002; Andersen et al. 2005; Pulido et al. 2011). Therefore, the overall outcome of increased sediment mineralization depends on the ability of isoetids to oxidize their rhizosphere (Pulido et al. 2011), and an effective oxidation of the rhizosphere partly depends on plant density (Tessenow and Baynes 1978). While a solitary plant might have difficulties to maintain an oxic rhizosphere, a dense mat of plants could build up a high $\mathrm{O}_{2}$ bulk during the day and thereby prevent anoxic conditions overnight (Tessenow and Baynes 1978).

In the present investigation, our aim was to test whether alkalinity and $\mathrm{SO}_{4}{ }^{2-}$ in surface water can directly affect the isoetid L. dortmanna, and whether potential impacts can be counteracted by higher plant density. Therefore, we tested the interactive effect of three surface water qualities (1) control, (2) high alkalinity and (3) a combination of high alkalinity and $\mathrm{SO}_{4}{ }^{2-}$ at three plant densities ("Low" $=64$ plants $\mathrm{m}^{-2}$, "Medium" $=256$ plants $\mathrm{m}^{-2}$ and "High" = 1,024 plants $\mathrm{m}^{-2}$ ) on L. dortmanna. We hypothesized that (a) alkaline water effects on plant performance would depend on the balance between the positive (high $\mathrm{CO}_{2}$ availability) and the negative (reduced conditions) effects related to an increase in sediment mineralization; (b) the combination of high alkalinity and $\mathrm{SO}_{4}{ }^{2-}$ would negatively affect the plants, since they might be exposed to multiple stressors such as reduced sediment conditions and phytotoxicity; and (c) high plant density would counteract the negative effects by oxidation of the rhizosphere. 


\section{Materials and methods}

\section{Experimental design}

A multifactorial experiment was designed to study the effects of alkalinity and $\mathrm{SO}_{4}{ }^{2-}$ on L. dortmanna growing at three densities: "Low" (64 plants $\mathrm{m}^{-2}$ ), "Medium" (256 plants $\left.\mathrm{m}^{-2}\right)$ and "High" (1,024 plants $\mathrm{m}^{-2}$ ). These densities were exposed to three water treatments: "Control" ( $3 \mathrm{mM} \mathrm{NaCl}$; to keep the ion level similar to "Alk" and " $\mathrm{SO}_{4}{ }^{2-}+\mathrm{Alk}$ "), "Alk" (1 $\mathrm{mM} \mathrm{Ca}\left(\mathrm{HCO}_{3}\right)_{2}$ and $\left.2 \mathrm{mM} \mathrm{NaCl}\right)$ and "SO $\mathrm{SO}_{4}{ }^{2-}+\mathrm{Alk}$ " $\left(1 \mathrm{mM} \mathrm{Ca}\left(\mathrm{HCO}_{3}\right)_{2}, 1 \mathrm{mM} \mathrm{Na}_{2} \mathrm{SO}_{4}\right.$, $1 \mathrm{mM} \mathrm{NaCl})$. The concentrations used are characteristic for local groundwater and river water in The Netherlands (Smolders et al. 2006). Each treatment was randomly assigned to an aquarium (see below) and replicated four times.

Thirty-six aquaria (length $=12.5 \mathrm{~cm}$, width $=$ $12.5 \mathrm{~cm}$, height $=31 \mathrm{~cm}$ ) were placed in a water jacket and maintained at $20 \pm 1{ }^{\circ} \mathrm{C}$ by means of a recirculation chiller (Neslab Merlin M-75; Thermo Scientific, Newington, NH, USA). Irradiance was $200 \mu \mathrm{mol} \mathrm{m} \mathrm{m}^{-2} \mathrm{~s}^{-1}$ and was provided by six Philipstype HP 400-W lamps (Hortilux-Schréder, Monster, The Netherlands) at a photoperiod of $12 \mathrm{~h}$. The aquaria were filled with $15 \mathrm{~cm}(2.5 \mathrm{~L})$ of fresh oligotrophic poorly buffered sediment collected from the softwater lake Banen (The Netherlands, $\left.51^{\circ} 16^{\prime} 09 \mathrm{~N}, 05^{\circ} 48^{\prime} 05 \mathrm{E}\right)$. Banen sediment had $48.6 \pm$ $0.9 \%$ of water, a density of $1.35 \pm 0.05 \mathrm{~kg} \mathrm{~L}^{-1}$ (fresh sediment), and contained $10.3 \pm 0.2 \%$ of organic matter (dry mass). For the fresh Banen sediment, plant available $\mathrm{P}$ (Olsen et al. 1954) was $43.4 \pm 27.0 \mu \mathrm{M}$, plant available $\mathrm{NO}_{3}{ }^{-}$and $\mathrm{NH}_{4}{ }^{+}$was $58.9 \pm 1.8$ and $246.2 \pm 24.5 \mu \mathrm{M}$, respectively. Nitrate and $\mathrm{NH}_{4}{ }^{+}$were extracted using $\mathrm{NaCl}(50 \mathrm{~mL}$ of $0.1 \mathrm{~mol} \mathrm{~L}{ }^{-1} \mathrm{NaCl}$ per $17.5 \mathrm{~g}$ of fresh sediment). Total $\mathrm{Fe}$ was $45.1 \pm 21.3 \mathrm{mM}$, and total $\mathrm{S}$ was $92.9 \pm 97.2 \mathrm{mM}$, both determined by digesting $200 \mathrm{mg}$ dry sediment in $4 \mathrm{~mL} \mathrm{HNO}_{3}(65 \%)$ and $1 \mathrm{~mL} \mathrm{H}_{2} \mathrm{O}_{2}(30 \%)$, using an Ethos $\mathrm{D}$ microwave (Milestone, Sorisole Lombardy, Italy). Analyses of $\mathrm{Fe}$ and $\mathrm{S}$ from digestates were carried out using an inductively coupled plasma emission spectrophotometer (ICP-MS; IRIS-OES model Intrepid II XDL; Thermo Fisher Scientific, Waltham, MA, USA). The water column $(13 \mathrm{~cm}, 2 \mathrm{~L})$ was continuously refreshed by pumping $3.6 \mathrm{~L}$ fresh medium $\mathrm{d}^{-1}$ from black containers into the aquaria using peristaltic pumps (Masterflex, 7015-20; Cole-Parmer, Vernon Hills, IL, U.S.A.). The water level in the aquaria was kept constant at $13 \mathrm{~cm}$ above the sediment using an overflow system.

"Low", "Medium" and "High" plant densities were obtained by carefully planting 1 (in the middle of the aquarium), 4 (square formation) and 16 (four rows by four columns) L. dortmanna plants, respectively. Plants were collected from Barstadvatn (Norway, $58^{\circ} 24^{\prime} 03^{\prime \prime} \mathrm{N}, 6^{\circ} 16^{\prime} 01^{\prime \prime} \mathrm{E}$ ), and the initial dry mass of individual plants was $48.6 \pm 33.0 \mathrm{mg}$. To stimulate sulfate reduction and thus the formation of sulfide, $20 \mathrm{~g}$ of cellulose was dissolved in $200 \mathrm{~mL}$ of demineralized water and carefully injected into all the sediments. Prior to the injection, the cellulose solution was bubbled with nitrogen to achieve anoxic conditions.

Plant analyses

After 3-month exposure to the three treatments, plants were counted and actual photosynthetic efficiency was measured at the middle of the 3rd, 6th and the oldest leaves of $L$. dortmanna plants by using a pulseamplitude modulated chlorophyll fluorometer (Walz, Junior-PAM-200, Effeltrich, Germany). The mean of the three measurements was used for the analysis of the data. Actual photosynthetic efficiency was measured, in each aquarium, on one plant at low plant density treatment, and on four plants, representative for the treatment, at medium and high plant density treatments. All plants were carefully harvested and washed with demineralized water. Mortality, expressed as \% of dead plants per aquarium, was measured counting the number of dead plants. A plant was considered dead when its actual photosynthetic efficiency was $<0.3$ and its tissues were visually substantially damaged; that is, $>50 \%$ of the plant tissue was discolored (close to white) and/or in a (partly) decomposed state (loss of internal cellular material). Live plants were then divided into shoot, root and corms, and dry mass $\left(24 \mathrm{~h}\right.$ drying at $70^{\circ} \mathrm{C}$ ) of each plant was measured. Plant biomass was expressed as the dry mass of live plants per $\mathrm{m}^{-2}$ and individual plant mass.

Sulfide intrusion is difficult to measure directly (Pedersen et al. 2004) and thus, we measured total $\mathrm{S}$ and $\delta^{34} \mathrm{~S}$ and used these as indicators of $\mathrm{H}_{2} \mathrm{~S}$ intrusion (Mascaró et al. 2009). While total S could 
indicate exposure to $\mathrm{H}_{2} \mathrm{~S}$, caution must be taken since low total $\mathrm{S}$ values can result from both low exposures to $\mathrm{H}_{2} \mathrm{~S}$ or high growth rates where $\mathrm{S}$ is diluted in fast-growing tissues (Christiansen et al. 1985). Moreover, total $\mathrm{S}$ does not allow determining whether $\mathrm{S}$ enters into the plant as $\mathrm{SO}_{4}{ }^{2-}$ or as $\mathrm{H}_{2} \mathrm{~S}$. Thus, we analyzed $\delta^{34} \mathrm{~S}$, which is an excellent indicator of $\mathrm{H}_{2} \mathrm{~S}$ intrusion where a low $\delta^{34} \mathrm{~S}$ signal indicates $\mathrm{H}_{2} \mathrm{~S}$ intrusion since the respiration of $\mathrm{SO}_{4}{ }^{2-}$ by reducing bacteria results in more of the lighter sulfur isotopes (Fry et al. 1982; Frederiksen et al. 2008). To measure total sulfur (S) and isotopic sulfur composition $\left(\delta^{34} \mathrm{~S}\right)$, plant material was dried and homogenized (Ball mill MM301, Haan, Germany). For total $\mathrm{S}$ analysis, $200 \mathrm{mg}$ of dried and homogenized material was digested in $4 \mathrm{~mL} \mathrm{HNO}_{3}$ $(65 \%)$ and $1 \mathrm{~mL} \mathrm{H}_{2} \mathrm{O}_{2}(30 \%)$ using a mega microwave (Milestone type MLS 1200, Sorisole Lombardy, Italy). The digestives were analyzed using an ICP-MS as above. For the sulfur isotopic composition $\left(\delta^{34} \mathrm{~S}\right)$ analysis, homogenized dry leaf and root material was weighed into tin capsules together with vanadium pentoxide. Sulfur isotopic composition was measured using elemental analyzer isotope ratio mass spectroscopy (EA-IRMS) at Isoanalytical (Iso-Analytical Limited, Crewe, Cheshire, UK). Due to the limited amount of plant material available, only one replica from each treatment was analyzed for sulfur isotopic composition.
Surface water and porewater analyses

Surface and sediment porewater samples were collected for chemical analysis monthly. Surface water samples were collected by submerging a bottle $(50 \mathrm{~mL})$ in the surface water. Porewater samples were collected without air contact with 5-cm-long sediment moisture samplers (Rhizon SMS-5 cm; Eijkelkamp Agrisearch Equipment, Wageningen, The Netherlands) that were installed vertically at a depth of 1 to $6 \mathrm{~cm}$ and connected to $120-\mathrm{mL}$ vacuum serum bottles. Samples were analyzed for $\mathrm{pH}$, alkalinity, total $\mathrm{S}$, total inorganic carbon $\left(\mathrm{CO}_{2}, \mathrm{HCO}_{3}{ }^{-}\right.$and $\left.\mathrm{CO}_{3}{ }^{2-}\right)$ and $\mathrm{CH}_{4}$, $\mathrm{NO}_{3}{ }^{-}, \mathrm{NH}_{4}{ }^{+}$and $\mathrm{PO}_{4}{ }^{3-}$ (Table 1 ; see stats in caption of Table 1). Alkalinity and $\mathrm{pH}$ of the water samples were measured using a Radiometer titrator (TIM 840 titration manager, Villeurbanne, France) Total S was measured using ICP-MS as described above. Total inorganic $\mathrm{C}$ was measured by infrared analysis (Advance Optima Infrared Gas Analyzer, ABB, Cary, $\mathrm{NC}, \mathrm{USA})$. Concentrations of $\mathrm{NO}_{3}{ }^{-}, \mathrm{NH}_{4}{ }^{+}$and $\mathrm{PO}_{4}{ }^{3-}$ were measured by colorimetry (Auto Analyzer, model III, Bran \& Luebbe, Norderstedt, Germany) using hydrazine $\mathrm{SO}_{4}{ }^{2-}$ (Kamphake et al. 1967), salicylate (Grasshoff and Johannsen 1972), ammonium molybdate (Henriksen 1965), respectively. In porewater, $\mathrm{H}_{2} \mathrm{~S}$ concentrations were measured by collecting $10 \mathrm{~mL}$ of porewater (extracted as previously explained), immediately fixed with $10 \mathrm{~mL}$ of $\mathrm{H}_{2} \mathrm{~S}$

Table 1 Surface water and pore water characteristics as a function of surface water treatments

\begin{tabular}{|c|c|c|c|c|c|}
\hline & Control & Alk & $\mathrm{SO}_{4}{ }^{2-}+\mathrm{Alk}$ & $\mathrm{H}_{d f}=2,33$ & $P$ \\
\hline \multicolumn{6}{|l|}{ Surface water } \\
\hline $\mathrm{pH}$ & $5.9 \pm 0.3^{\mathrm{a}}$ & $7.4 \pm 0.3^{\mathrm{b}}$ & $7.3 \pm 0.2^{\mathrm{b}}$ & 23.8 & $* * *$ \\
\hline Alkalinity $\left(\mu \mathrm{mol} \mathrm{L}{ }^{-1}\right)$ & $155 \pm 42^{\mathrm{a}}$ & $1,423 \pm 966^{\mathrm{b}}$ & $1,408 \pm 1,006^{\mathrm{b}}$ & 23.4 & $* * *$ \\
\hline Total $\mathrm{S}(\mu \mathrm{M})$ & $74 \pm 45^{\mathrm{a}}$ & $54 \pm 73^{\mathrm{a}}$ & $1,169 \pm 1,211^{\mathrm{b}}$ & 24.5 & $* * *$ \\
\hline $\mathrm{CO}_{2}(\mu \mathrm{M})$ & $148 \pm 385^{\mathrm{a}}$ & $59 \pm 111^{\mathrm{a}}$ & $33 \pm 45^{\mathrm{a}}$ & 2.6 & ns \\
\hline \multicolumn{6}{|l|}{ Pore water } \\
\hline $\mathrm{pH}$ & $4.9 \pm 0.3^{\mathrm{a}}$ & $5.4 \pm 0.6^{\mathrm{ab}}$ & $5.5 \pm 0.4^{\mathrm{b}}$ & 11.5 & $* *$ \\
\hline Alkalinity $\left(\mu \mathrm{mol} \mathrm{L}{ }^{-1}\right)$ & $1,315 \pm 632^{\mathrm{a}}$ & $4,299 \pm 6,431^{\mathrm{ab}}$ & $3,654 \pm 1,709^{b}$ & 11.6 & $* *$ \\
\hline $\mathrm{S}(\mu \mathrm{M})$ & $108 \pm 98^{\mathrm{a}}$ & $109 \pm 96^{\mathrm{a}}$ & $781 \pm 944^{\mathrm{b}}$ & 9.1 & $*$ \\
\hline $\mathrm{H}_{2} \mathrm{~S}(\mu \mathrm{M})$ & $0.1 \pm 0.1^{\mathrm{ab}}$ & $0.1 \pm 0.0^{\mathrm{a}}$ & $0.3 \pm 0.1^{\mathrm{b}}$ & 16.4 & $* *$ \\
\hline $\mathrm{CO}_{2}(\mu \mathrm{M})$ & $612 \pm 1,382^{\mathrm{a}}$ & $1,476 \pm 1,261^{\mathrm{b}}$ & $1,348 \pm 1,196^{\mathrm{b}}$ & 15.2 & $* * *$ \\
\hline
\end{tabular}

Means $(n=12, \pm \mathrm{SD})$ of $\mathrm{pH}$, alkalinity $\left(\mu\right.$ moles acid equivalents $\left.\mathrm{L}^{-1}\right)$, total $\mathrm{S}(\mu \mathrm{M}), \mathrm{H}_{2} \mathrm{~S}(\mu \mathrm{M})$, and $\mathrm{CO}_{2}(\mu \mathrm{M})$ at the end of the experiment are shown for "Control", "Alk" and " $\mathrm{SO}_{4}{ }^{2-}+\mathrm{Alk}$ " treatments. Test significance is indicated by $\mathrm{H}$, and the $P$ value (ns $P>0.05, * P<0.05$, ** $P<0.01$, *** $P<0.001$ ). Means with the same letter do not differ significantly at $95 \% \mathrm{CI}$

$d f$, degrees of freedom 
antioxidant buffer containing $\mathrm{NaOH}$ (to convert all $\mathrm{H}_{2} \mathrm{~S}$ and $\mathrm{HS}^{-}$into $\mathrm{S}^{2-}$ ), Na-EDTA and ascorbic acid (van Gemerden 1984). Hydrogen sulfide concentrations were subsequently measured using an $\mathrm{S}^{2-}$ specific Ag electrode (Orion Research, Beverly, CA, USA) and a double-junction calomel reference electrode (Roelofs 1991). Data for the three plant density treatments were combined in Table 1 , because plant density did not significantly affect water parameters. The concentration in surface and porewater of $\mathrm{NO}_{3}{ }^{-}$, $\mathrm{NH}_{4}{ }^{+}$and $\mathrm{PO}_{4}{ }^{3-}$ was not significantly affected by water treatment (data not shown). On average $(n=36)$, surface water contained $7.9 \pm 1.6 \mu \mathrm{M} \mathrm{NO}_{3}{ }^{-}, 5.9 \pm$ $2.7 \mathrm{MM} \mathrm{NH}_{4}{ }^{+}$and $2.1 \pm 1.9 \mu \mathrm{MPO}_{4}{ }^{3-}$; and porewater contained $7.8 \pm 3.7 \mu \mathrm{M} \mathrm{NO}_{3}{ }^{-}, 4.7 \pm 3.4 \mu \mathrm{M} \mathrm{NH}_{4}{ }^{+}$ and $0.9 \pm 0.8 \mu \mathrm{M} \mathrm{PO}_{4}{ }^{3-}$.

\section{Sediment analyses}

The biological $\mathrm{O}_{2}$ demand (BOD) of all sediments at the time of harvesting was measured by incubating $5 \mathrm{~mL}$ of fresh sediment in 50-mL glass bottles in the dark in air saturated water solution. Smart and Barko solution (Smart and Barko 1985) adjusted to $0.1 \mathrm{mEq}$ was used as water solution for all sediments independently of the treatment. Sediment samples were first pre-incubated for $12 \mathrm{~h}$ in $5 \mathrm{~mL}$ of aerated water to eliminate chemical $\mathrm{O}_{2}$ demand. Bottles were then filled with aerated water, closed and incubated in the dark under stirred condition for a known period of time (from 2 to $4 \mathrm{~h}$ depending on BOD). Oxygen concentrations were measured before and after incubation using an $\mathrm{O}_{2}$ mini-electrode (OX500 Unisense, Aarhus, Denmark). Biological $\mathrm{O}_{2}$ demand was calculated as $\mathrm{O}_{2}$ demand per sediment volume and unit time (nmol O $\mathrm{L}^{-1} \mathrm{~s}^{-1}$ ).

Redox potential as a proxy of the prevailing electrons acceptors in the surrounding sediment provides valuable information on (a) the oxidation status of the sediment and (b) the oxygen depletion caused by sediment mineralization. Redox potential was measured monthly during daylight, $1-3 \mathrm{~h}$ into the light period. Measurements were taken at $1.5 \mathrm{~cm}$ from the middle of the aquaria at 5 depths $(1.5,3,6$, 9 and $12 \mathrm{~cm}$ ). Redox potential was measured using a platinum electrode and a Metrohm $\mathrm{AgCl} / \mathrm{KCl}$ reference electrode (Metrohm, Herisau, Switzerland) connected to a $\mathrm{mV} / \mathrm{pH}$ meter (Radiometer Nederland BV, Zoetermeer, The Netherlands). The electrical potentials measured were converted to redox potentials relative to the standard hydrogen potential measured $\left(E_{\mathrm{h}}\right)$ by adding the reference $(210 \mathrm{mV})$ and correcting for temperature and porewater $\mathrm{pH}$ as follows:

$$
\begin{aligned}
E_{\mathrm{h}}= & \left(E_{\text {measured }}+E_{\text {reference }}\right) \\
& +\left(0.2 * 293 *\left(p H_{\text {measured }}-7\right)\right) .
\end{aligned}
$$

Statistical analyses

Data were statistically analyzed by SPSS 17.0.0 (SPSS Inc., Chicago, USA), Prism 5.01 (GraphPad Software, Inc. La Jolla, USA) and Microsoft Excel 2010 (Microsoft Office, Redmond, WA). Data were transformed by $x=\operatorname{Ln}(x+1)$ or $x=\operatorname{Sqrt}(x+0.5)$ to improve the normality when necessary. Normality was checked by Shapiro-Wilk and homogeneity by Levene's test. To assess the effect of water and plant density treatments, parametric data were analyzed using one- or two-way ANOVA followed by Bonferroni's multiple comparison test. Nonparametric data were analyzed by Kruskal-Wallis or the extension of Kruskal-Wallis test (Scheirer et al. 1976), followed by Dunn's multiple comparison test. Graphs were drawn with Prism 5.01 (GraphPad Software, Inc. La Jolla, USA). Data are presented as means \pm SD. Differences are considered significant when $P<0.05$.

\section{Results}

Mortality, biomass and actual photosynthetic efficiency

The overall aim of this study was to test if the joint action of increased water column concentration of $\mathrm{SO}_{4}{ }^{2-}$ and alkalinity, above those typical for pristine softwater lakes with healthy populations of isoetids, adversely affected L. dortmanna, and whether potential impacts can be counteracted by high plant density. Essentially, the combination of $\mathrm{SO}_{4}{ }^{2-}$ and alkalinity negatively affected L. dortmanna and caused mortality, lowered the areal biomass and reduced actual photosynthetic efficiency (Table 2, Fig. 1). Plant density did not significantly counteract the negative effects caused by the combination of $\mathrm{SO}_{4}{ }^{2-}$ and alkalinity. However, actual photosynthetic efficiency was significantly positively correlated to redox 
potential in the sediment, indicating a positive relationship between plant performance and sediment oxidation.

The combination of $\mathrm{SO}_{4}{ }^{2-}$ and alkalinity had a significant effect on plant mortality especially at "Low" plant density, where $75 \%$ of the plants died (Fig. 1a-c, Table 2). In the "Control" treatment, some plants died. In contrast to the other treatments, this mortality only occurred in one replica of one specific density treatment (Medium), indicating it was very likely caused by an exceptional factor we could not account for (Fig. 1b). The combination of $\mathrm{SO}_{4}{ }^{2-}$ and alkalinity also significantly decreased areal biomass measured as live tissue. After 3 months of optimal growth condition in the laboratory, areal biomass at " $\mathrm{SO}_{4}{ }^{2-}+$ Alk" did not differ from the initials (Fig. 1d-f). Plant density significantly affected on areal biomass and individual plant mass (Fig. 1g-i, Table 2). While areal biomass at "Low" and "Medium" density were significantly lower than "High", individual plant mass decreased from "Low" to "High" plant density. Similarly, " $\mathrm{SO}_{4}{ }^{2-}+$ Alk" significantly reduced actual photosynthetic efficiency (Fig. 2j-1, Table 2), which is widely used as a stress indicator (the lower the value the higher the stress;
Krause and Weis 1991). Those negative effects on areal biomass and photosynthetic efficiency tended to be alleviated by increasing plant density so that on average actual photosynthetic efficiency at " $\mathrm{SO}_{4}{ }^{2-}+\mathrm{Alk}$ " at "Low" density was 5-fold lower than at "Alk", but only 2.5-fold lower at "High" plant density. However, plant density did not significantly affect plant performance (Table 2). The dramatic decrease in actual photosynthetic efficiency at " $\mathrm{SO}_{4}{ }^{2-}+$ Alk" can partly be explained by the fact that actual photosynthetic efficiency was also measured on dying plants with a high proportion of damaged tissues.

\section{Biological oxygen demand and redox potential}

At the end of the experiment, potential biological oxygen demand was high in all treatments (mean \pm $\mathrm{SD}=178.7 \pm 38.6 \mathrm{nmol} \mathrm{L}^{-1} \mathrm{~s}^{-1}$ ). Alkalinity by itself or in combination of $\mathrm{SO}_{4}{ }^{2-}$ did not statistically differed from "Control" treatment (Fig. 2a-c, Table 2). Potential biological oxygen demand at " $\mathrm{SO}_{4}{ }^{2-}+$ Alk" was highest, although the effect was significant only at "High" plant density compared to "Alk" treatment (Fig. 2a-c).
Table 2 Effects of water quality, plant density and their interaction on plant mortality, total biomass, individual plant mass and actual photosynthetic efficiency $(\mathrm{Fv} / \mathrm{Fm})$ of Lobelia dortmanna and potential biological $\mathrm{O}_{2}$ demand (BOD) and redox potential of the sediment at the end of the experiment at several depths

\begin{tabular}{|c|c|c|c|c|c|c|c|c|c|}
\hline & \multicolumn{4}{|c|}{ Water quality $d f=2,27$} & \multicolumn{4}{|c|}{ Plant density $d f=2,27$} & \multirow{2}{*}{$\begin{array}{l}\text { Interaction } d f=4,27 \\
F \text { or } \mathrm{H}, P\end{array}$} \\
\hline & $F$ or $\mathrm{H}, P$ & "C" & "A" & $" S+A "$ & $F$ or $\mathrm{H}, P$ & "L" & "M" & "H" & \\
\hline \multicolumn{10}{|l|}{ Lobelia dortmanna } \\
\hline Mortality & $9.0^{*}$ & a & a & $\mathrm{b}$ & $1.5 \mathrm{~ns}$ & $\mathrm{x}$ & $\mathrm{x}$ & $\mathrm{x}$ & $1.6 \mathrm{~ns}$ \\
\hline Biomass & $6.6^{*}$ & $a b$ & a & $\mathrm{b}$ & $15.1 * * *$ & $\mathrm{y}$ & $\mathrm{y}$ & $\mathrm{x}$ & $2.9 \mathrm{~ns}$ \\
\hline Individual plant mass & $10.4 * * *$ & $a b$ & a & $\mathrm{b}$ & $11.9 * * *$ & $\mathrm{x}$ & $\mathrm{y}$ & $\mathrm{z}$ & $4.1^{*}$ \\
\hline $\mathrm{Fv} / \mathrm{Fm}$ & $20.1 * * *$ & a & a & $\mathrm{b}$ & $1.0 \mathrm{~ns}$ & $\mathrm{x}$ & $\mathrm{x}$ & $\mathrm{x}$ & $0.3 \mathrm{~ns}$ \\
\hline \multicolumn{10}{|l|}{ Sediment } \\
\hline BOD & $5.5^{* *}$ & $a b$ & $\mathrm{~b}$ & a & $1.7 \mathrm{~ns}$ & $\mathrm{x}$ & $\mathrm{x}$ & $\mathrm{x}$ & $1.8 \mathrm{~ns}$ \\
\hline \multicolumn{10}{|l|}{ Redox potential } \\
\hline $1.5 \mathrm{~cm}$ depth & $6.8 * *$ & $\mathrm{a}$ & a & $\mathrm{b}$ & $4.5 *$ & xy & $\mathrm{y}$ & $\mathrm{x}$ & $1.4 \mathrm{~ns}$ \\
\hline $3 \mathrm{~cm}$ depth & $6.7 * *$ & $a b$ & a & $\mathrm{b}$ & $3.9 *$ & $\mathrm{x}$ & $\mathrm{x}$ & $\mathrm{x}$ & $1.2 \mathrm{~ns}$ \\
\hline $6 \mathrm{~cm}$ depth & $14.0 * * *$ & $\mathrm{a}$ & $\mathrm{a}$ & $\mathrm{b}$ & $5.0 *$ & $\mathrm{x}$ & $\mathrm{x}$ & $\mathrm{x}$ & $2.8 *$ \\
\hline $9 \mathrm{~cm}$ depth & $11.2 * * *$ & $\mathrm{a}$ & $\mathrm{a}$ & $\mathrm{b}$ & $0.3 \mathrm{~ns}$ & $\mathrm{x}$ & $\mathrm{x}$ & $\mathrm{x}$ & $1.2 \mathrm{~ns}$ \\
\hline $12 \mathrm{~cm}$ depth & $6.9 * *$ & $\mathrm{a}$ & $\mathrm{a}$ & $\mathrm{b}$ & $0.3 \mathrm{~ns}$ & $\mathrm{x}$ & $\mathrm{x}$ & $\mathrm{x}$ & $0.9 \mathrm{~ns}$ \\
\hline
\end{tabular}

Test significance is indicated by $\mathrm{H}$ (for Kruskal-Wallis test) or $F$ (for ANOVA test) and the $P$ value (ns $P>0.05, * P<0.05$, $* * P<0.01$, *** $P<0.001)$. Means with the same letter do not differ significantly at $95 \% \mathrm{CI}$

$d f$, degrees of freedom; $C$, "control"; $A$, "Alk"; $S+A$, "SO${ }_{4}{ }^{2-}+\mathrm{Alk} " ; L$, "low"; $M$, "medium"; $H$, "high" 


\section{Plant density}

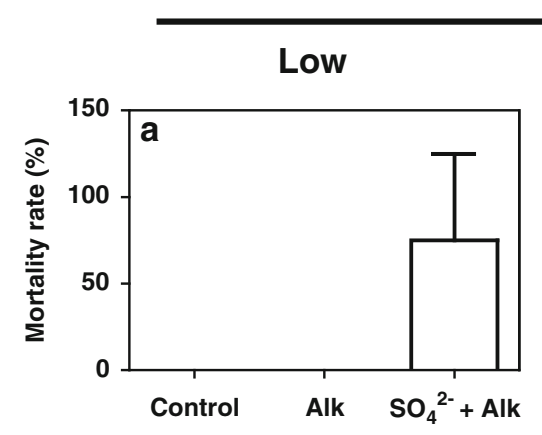

Medium
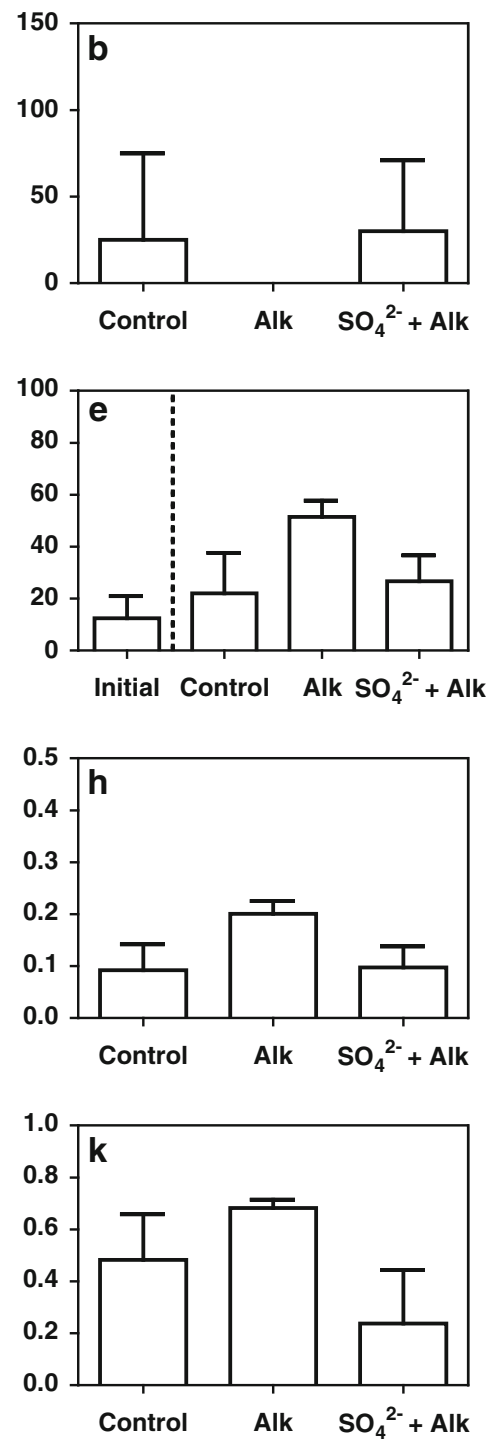

High
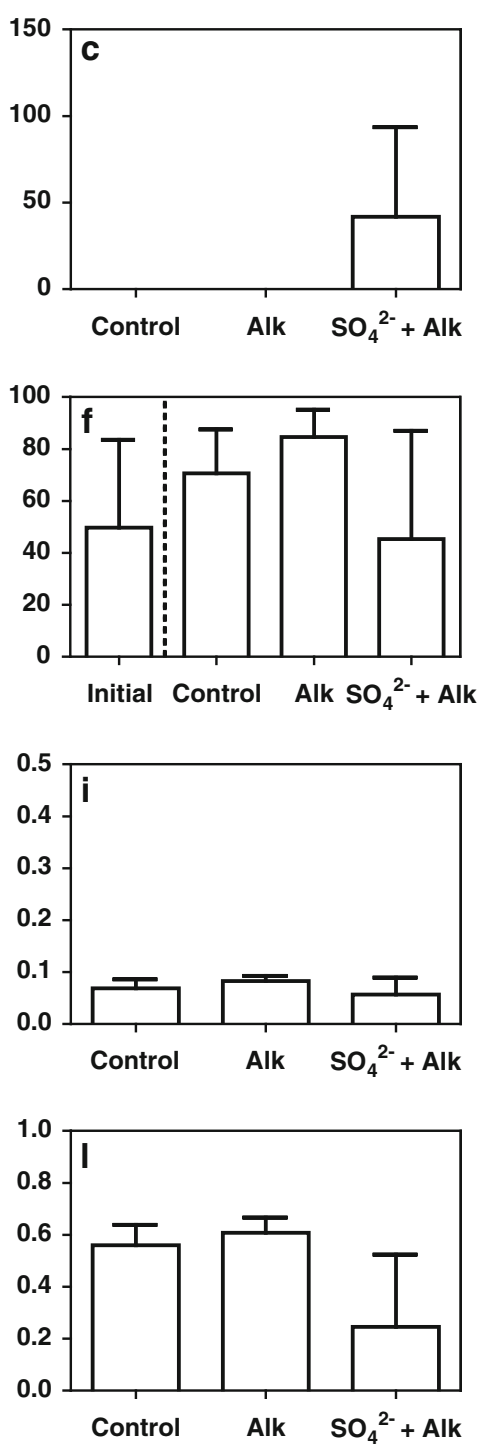

Fig. 1 Plant parameters as a function of water quality at "Low", "Medium" and "High" plant density. Means $(n=4$, $\mathrm{SD})$ of mortality rate $(\% ; \mathbf{a}-\mathbf{c})$, total biomass $\left(\mathrm{g} \mathrm{DM} \mathrm{m} \mathrm{m}^{-2} ; \mathbf{d}-\mathbf{f}\right)$,

Sediment redox potentials at the water column treatment " $\mathrm{SO}_{4}{ }^{2-}+\mathrm{Alk}$ " were significantly lower than at "Alk" (Fig. 2d-f, Table 2), indicating higher mineralization rates in the sediment and/or lower radial oxygen loss from plants. Plant density also significantly affected the redox potential so that sediment redox potential in the rhizosphere (up to $6 \mathrm{~cm}$ depth) in general increased with increasing plant individual plant mass (g DM, g-i) and actual photosynthetic efficiency (Fv/Fm; $\mathbf{j}-\mathbf{l})$ of Lobelia dortmanna are shown for each water treatment ("Control", "Alk", " $\mathrm{SO}_{4}{ }^{2-}+\mathrm{Alk} "$ )

density (Fig. 2d-f, Table 2). However, at "Low" density, plants were unable to oxidize the sediment and there were no visual differences in sediment redox potentials between the rhizosphere and the deeper sediment (Fig. 2d).

Actual photosynthetic efficiency was significantly positively correlated to redox potential in the sediment, indicating a positive relationship between plant 


\section{Plant density}
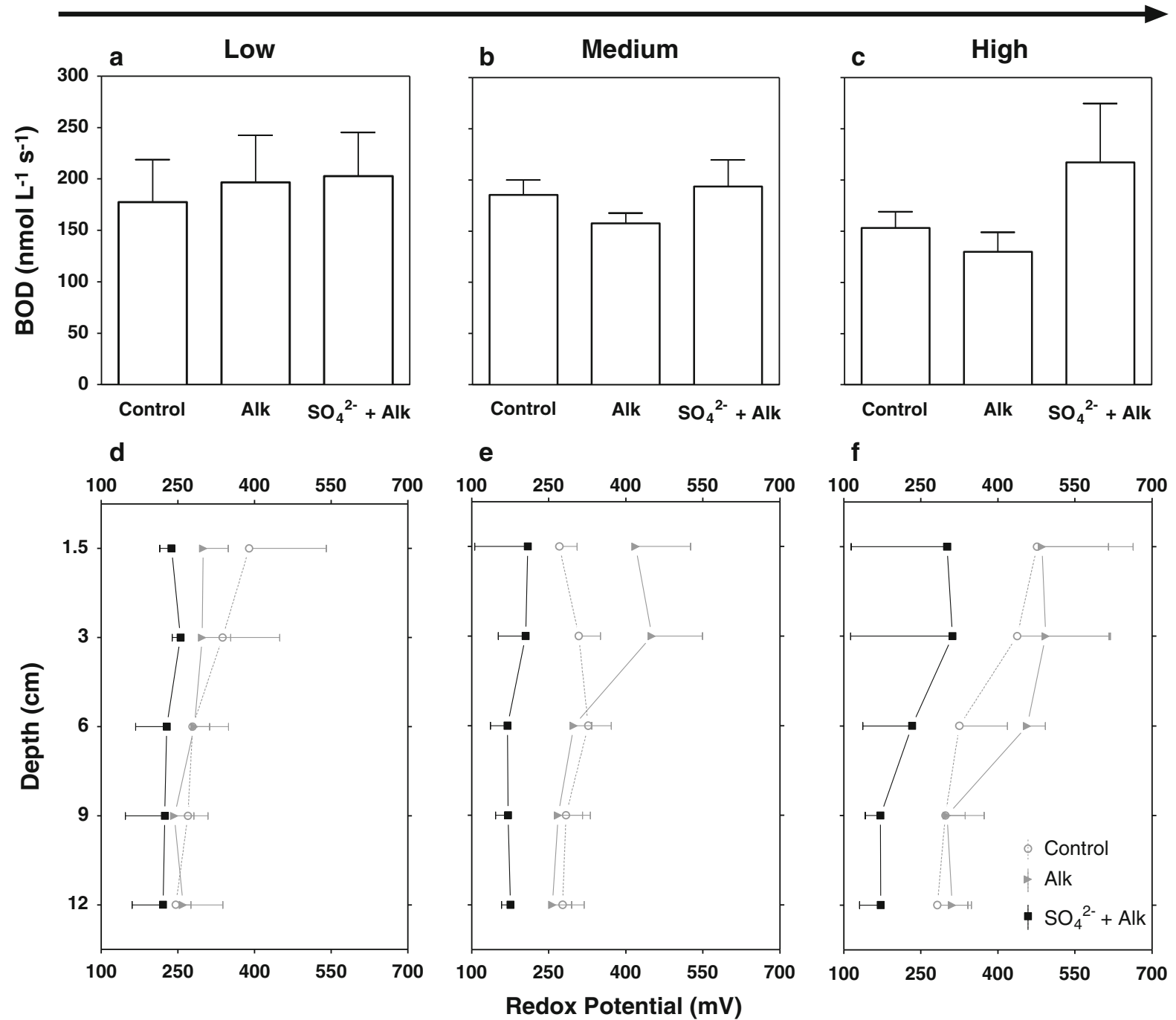

Fig. 2 Potential biological $\mathrm{O}_{2}$ demand (BOD, nmol L $\mathrm{L}^{-1} \mathrm{~s}^{-1}$ ) and redox potential $\left(\mathrm{E}_{\mathrm{h}}, \mathrm{mV}\right)$ as a function of water quality at "Low", "Medium" and "High" plant density. Means $(n=4$, $\mathrm{SD})$ of BOD $(\mathbf{a}-\mathbf{c})$ measured after harvesting, and redox potential $(\mathbf{d}-\mathbf{f})$ measured $1.5 \mathrm{~cm}$ from the nearest plant at several depths $(1.5-12 \mathrm{~cm})$ during the day time just before harvesting for "Control", "Alk", "SO${ }_{4}{ }^{-}+$Alk" treatments performance and sediment oxidation (Fig. 3). Remarkable, $80 \%$ of the " $\mathrm{SO}_{4}{ }^{2-}+$ Alk" aquaria had average actual photosynthetic efficiency $<0.3$ threshold for dead plants in this study.

Sulfate respiration and generation of $\mathrm{H}_{2} \mathrm{~S}$

In general, shoots and roots of L. dortmanna grown at " $\mathrm{SO}_{4}{ }^{2-}+\mathrm{Alk}$ " had a significantly higher total $\mathrm{S}$ content than "Control" and "Alk" treatments; only at "High" plant density, total shoot $\mathrm{S}$ did not differ between " $\mathrm{SO}_{4}{ }^{2-}+$ Alk" and "Control" (Table 3). Although total $\mathrm{S}$ followed a similar pattern in both shoots and roots, total $\mathrm{S}$ in shoots was 2- to 4-fold lower than in roots. The combination of $\mathrm{SO}_{4}{ }^{2-}$ and alkalinity resulted in $\delta^{34} \mathrm{~S}$ values lower than $5 \%$ in both shoots and roots of L. dortmanna (Fig. 4), although the effect was only significant in the root tissue. 


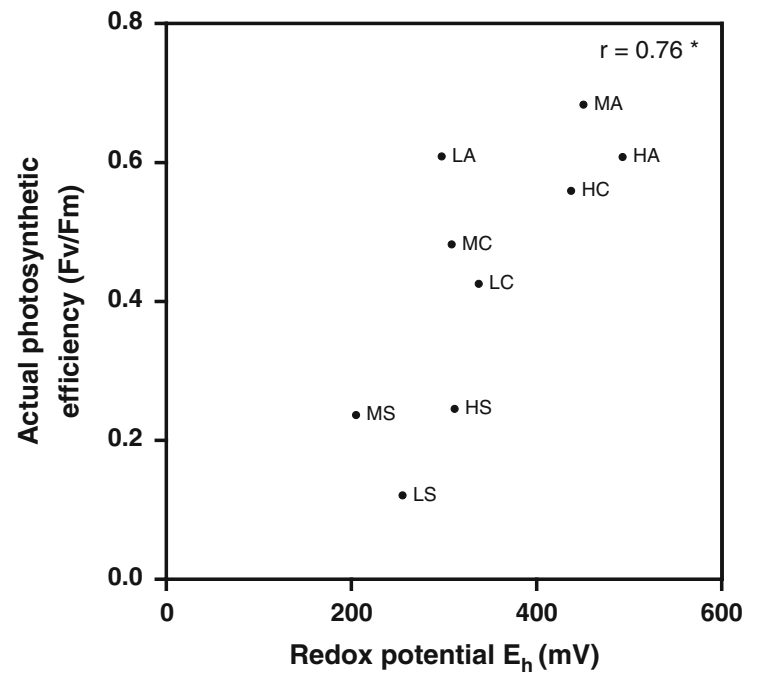

Fig. 3 Actual photosynthetic efficiency (Fv/Fm) versus redox potential. Each plot represents the mean actual photosynthetic efficiency of Lobelia dortmanna plants for each water ("Control" = C; "Alk" = A; "SO${ }_{4}{ }^{2-}+\mathrm{Alk} "=\mathrm{S}$ ) and plant density treatment ("Low" = L; "Medium" = M; "High" = H) versus the mean redox potential measured at $1.5 \mathrm{~cm}$ from the center of the aquarium at $3 \mathrm{~cm}$ of depth from the surface of the sediment. $n=9 ; r=$ Pearson's correlation; $* P<0.05$

\section{Discussion}

The combination of high $\mathrm{SO}_{4}{ }^{2-}$ and high alkalinity in surface water negatively affected $L$. dortmanna plants causing mortality, decreasing biomass and reducing actual photosynthetic. In contrast to our hypothesis, plant density did not significantly alleviate the negative effects caused by high $\mathrm{SO}_{4}{ }^{2-}$ and high alkalinity. However, there was a positive relationship between photosynthetic efficiency and redox potential in the sediment. In this section, firstly, we are discussing the

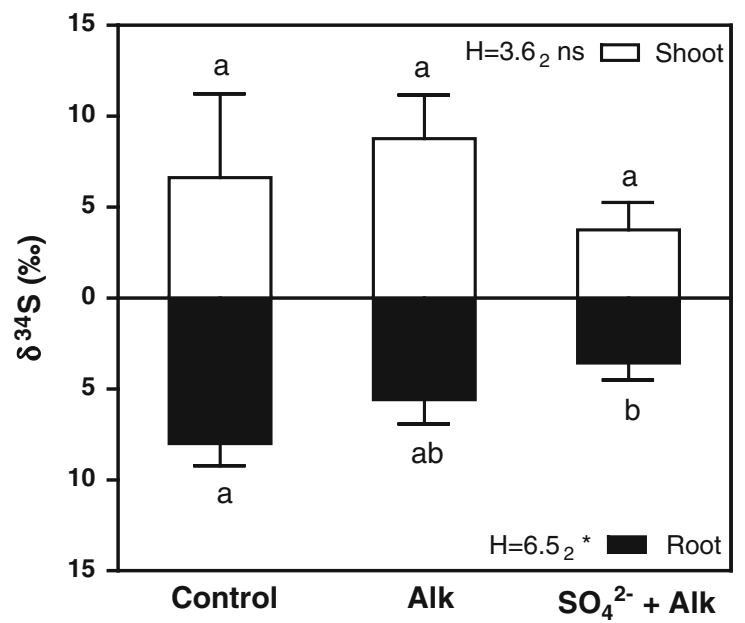

Fig. 4 Effects of water quality on $\delta^{34} \mathrm{~S}$ in shoots and roots of Lobelia dortmanna. Means $(n=3, \mathrm{SD})$ of $\delta^{34} \mathrm{~S}$ in shoots and roots are shown for different water qualities ("Control", "Alk" and " $\mathrm{SO}_{4}{ }^{2-}+\mathrm{Alk}$ "); values represent pooled averages of "Low", "Medium" and "High" plant densities. Test significance is indicated by $\mathrm{H}$, degree of freedom (subscript) and the $P$ value (ns $P>0.05, * P<0.05$ ). Means with the same letter do not differ significantly at $95 \%$ CI

possible causes of the negative effects produced by the combination of high $\mathrm{SO}_{4}{ }^{2-}$ and high alkalinity, that is, tissue anoxia or the combination of tissue anoxia and $\mathrm{H}_{2} \mathrm{~S}$ intrusion in the plant. Secondly, we are addressing the lack of significant plant density effect. And finally, we are also arguing why plants were not negative affected when they were exposed only to elevated levels of alkalinity.

It is possible that long periods of tissue anoxia can explain tissue damage observed in the " $\mathrm{SO}_{4}{ }^{2-}+$ Alk" treatment (Fig. 1), especially at "Low" and "Medium" plant density. Although it has recently been

Table 3 Total S in shoots and roots of Lobelia dortmanna as a function of water quality and plant density

\begin{tabular}{|c|c|c|c|c|c|c|}
\hline & Total S & Control & Alk & $\mathrm{SO}_{4}{ }^{2-}+\mathrm{Alk}$ & $F d f=2,9$ & $P$ \\
\hline \multirow[t]{2}{*}{ Low } & Shoot & $46<1^{b}$ & $22 \pm 1^{\mathrm{c}}$ & $144 \pm 7^{\mathrm{a}}$ & 97.4 & $* * *$ \\
\hline & Root & $93 \pm 1^{\mathrm{b}}$ & $91 \pm 1^{\mathrm{b}}$ & $264 \pm 18^{\mathrm{a}}$ & 351.4 & $* * *$ \\
\hline \multirow[t]{2}{*}{ Medium } & Shoot & $40 \pm 2^{\mathrm{b}}$ & $33<1^{\mathrm{b}}$ & $62 \pm 12^{\mathrm{a}}$ & 16.3 & $* * *$ \\
\hline & Root & $91 \pm 3^{b}$ & $98 \pm 2^{\mathrm{b}}$ & $158 \pm 33^{\mathrm{a}}$ & 14.37 & $* *$ \\
\hline \multirow[t]{2}{*}{ High } & Shoot & $62 \pm 3^{a}$ & $44 \pm 10^{\mathrm{b}}$ & $62 \pm 1^{\mathrm{a}}$ & 9.1 & $* *$ \\
\hline & Root & $124 \pm 22^{\mathrm{a}}$ & $105 \pm 9^{\mathrm{a}}$ & $159 \pm 4^{b}$ & 12.5 & $* *$ \\
\hline
\end{tabular}

Means $(n=4, \pm \mathrm{SD})$ of total $\mathrm{S}\left(\mu \mathrm{mol} \mathrm{g}{ }^{-1} \mathrm{DM}\right)$ are shown for the three different water qualities ("Control", "Alk" and "SO ${ }_{4}{ }^{2-}+$ Alk") at "Low", "Medium" and "High" plant density. Test significance is indicated by $F$, and the $P$ value (** $P<0.01$, $* * * P<0.001)$. Means with the same letter do not differ significantly at $95 \% \mathrm{CI}$

$d f$, degrees of freedom 
shown that L. dortmanna can tolerate short periods of tissue anoxia (Møller and Sand-Jensen 2011), longer periods of tissue hypoxia or anoxia reduce vascular translocation (Sorrell 2004), photosynthetic efficiency (Pulido and Borum 2010) and plant growth (Møller and Sand-Jensen 2011) and can even result in mortality of aquatic macrophytes (Sand-Jensen et al. 2005a; Raun et al. 2010). Leaf lacunae of L. dortmanna experienced anoxia for long periods in organically enriched sediments at approximately $15{ }^{\circ} \mathrm{C}$ and a plant density of c. 1,000 plants $\mathrm{m}^{-2}$ (Møller and Sand-Jensen 2011). In parallel, in situ experiments at similar organic addition resulted in BOD of $48 \mathrm{nmol} \mathrm{O}_{2} \mathrm{~L}^{-1} \mathrm{~s}^{-1}$ (Claus Møller, personal communication). Thus, it is likely that in the present study, belowground plant tissues at " $\mathrm{SO}_{4}{ }^{2-}+\mathrm{Alk}$ " experienced extended periods of anoxia during the night, as the plants were exposed to 4-fold higher BOD in the rhizosphere, higher temperatures and similar plant densities than in Møller and Sand-Jensen (2011) . Plants could even experience anoxia during the day at "Low" and "Medium" plant density in the " $\mathrm{SO}_{4}{ }^{2-}+\mathrm{Alk}$ " treatment as indicated by (a) the low redox potential $(<250 \mathrm{mV})$, which is similar to the redox potential in bare anoxic sediments in softwater lakes (Wium-Andersen and Andersen 1972; Andersen and Olsen 1994) and (b) the lack of visual differences in redox potential with depth (Fig. 2, Table 3), showing that plants were unable to oxidize the rhizosphere.

The combination of anoxia and $\mathrm{H}_{2} \mathrm{~S}$ toxicity would also explain the reduced plant performance in the " $\mathrm{SO}_{4}{ }^{2-}+\mathrm{Alk}$ " treatment (Fig. 1). Many sedimentdwelling microorganisms will start respiring $\mathrm{SO}_{4}{ }^{2-}$ to decompose organic matter when other energetically more favorable electrons acceptors have been depleted (Laanbroek 1990) and the $\mathrm{SO}_{4}{ }^{2-}$ reduction results in the generation of $\mathrm{H}_{2} \mathrm{~S}$, which is known as a strong phytotoxin (Holmer and Bondgaard 2001). Sulfide lowers photosynthesis (Pezeshki et al. 1988; Goodman et al. 1995), reduces growth (Koch and Mendelssohn 1989; Holmer and Nielsen 2007; Geurts et al. 2009), and ultimately reduces survival (Armstrong et al. 1996; Holmer and Bondgaard 2001) of wetland plants and aquatic macrophytes, even at porewater $\mathrm{H}_{2} \mathrm{~S}$ concentrations as low as $5 \mu \mathrm{M}$ (Smolders and Roelofs 1996). In the present study, we did not detect porewater $\mathrm{H}_{2} \mathrm{~S}$ concentrations above $0.5 \mu \mathrm{M}$ at " $\mathrm{SO}_{4}{ }^{2-}+$ Alk" (Table 1). Nevertheless, total $\mathrm{S}$ as well as $\delta^{34} \mathrm{~S}$ values clearly indicate a higher $\mathrm{H}_{2} \mathrm{~S}$ intrusion into roots in the " $\mathrm{SO}_{4}{ }^{2-}+\mathrm{Alk}$ " treatment in comparison with "Controls" and "Alk" (Table 3, Fig. 4). The direct comparison of $\delta^{34} \mathrm{~S}$ values with other isoetids is constrained by the lack of studies of $\mathrm{H}_{2} \mathrm{~S}$ intrusion in isoetids as the phenomenon has received little attention due to naturally low $\mathrm{SO}_{4}{ }^{2-}$ concentrations in oligotrophic softwater lakes (Holmer et al. 1998). In addition, isoetids loose most of the $\mathrm{O}_{2}$ produced in the photosynthesis via ROL so that the rhizosphere is often completely oxidized (Pedersen et al. 1995; Sand-Jensen et al. 2005b) and so, sulfate reduction is of little quantitative importance in isoetid populations. In seagrasses, however, $\mathrm{H}_{2} \mathrm{~S}$ intrusion has been extensively investigated and here, sulfate reduction is important due to naturally higher levels of $\mathrm{SO}_{4}{ }^{2-}$ (Holmer et al. 2003) and much lower rates of ROL from seagrasses (Jensen et al. 2005; Sand-Jensen et al. 2005b; Møller and Sand-Jensen 2008). $\delta^{34} \mathrm{~S}$ varies among species (Frederiksen et al. 2008), but $\delta^{34} \mathrm{~S}$ values for L. dortmanna fall within the lower range of those observed for seagrasses (Zostera marina, Posidonea oceanica; Holmer and Nielsen 2007; Frederiksen et al. 2008, or Cymodocea serrulata; Povidisa et al. 2009), although they are exposed to $\mathrm{H}_{2} \mathrm{~S}$ levels more than 100 -fold higher than $L$. dortmanna in the present study. Thus, we propose that $\mathrm{H}_{2} \mathrm{~S}$ intrusion in addition to tissue anoxia per se could explain the negative effects observed on plants exposed to elevated concentrations of $\mathrm{SO}_{4}{ }^{2-}$ and alkalinity in surface water.

Plant density did not significantly counteract the negative effect produced by the combination of high sulfate and high alkalinity (Table 2 ). However, photosynthetic efficiency is positive correlated to sediment redox, indicating a positive relationship between plant performance and sediment oxidation (Fig. 3). On average, areal biomass and photosynthetic efficiency tended to increase from "Low" to "High" plant density at " $\mathrm{SO}_{4}{ }^{2-}+\mathrm{Alk}$ " treatment (Fig. 1). However, this tendency was not significant (Table 2). The increase in plant density did not result in a proportional increase in plant biomass because plant density increase caused individual plant mass decrease (Fig. 1). Therefore, the negative effects expected especially at "Low" plant density (Tessenow and Baynes 1978) were probably counteracted by the lack of plant competence, which resulted in high individual plant mass and thus high availability to oxidize the sediment. 
Elevated levels of surface water alkalinity did not negatively affect plant performance (Fig. 1, Table 2). The elevated concentrations of $\mathrm{CO}_{2}$ in the porewater of "Alk" (Table 1) could be originated from (1) enhanced mineralization processes and/or (2) from diffusion of $\mathrm{HCO}_{3}{ }^{-}$from the alkaline surface water into the sediment where $\mathrm{HCO}_{3}{ }^{-}$was then converted into $\mathrm{CO}_{2}$ as a result of the lower $\mathrm{pH}$ in the porewater. Low BOD values in "Alk" treatment compared to "SO ${ }_{4}{ }^{2-}+$ Alk" (Fig. 2) could be the result of high mineralization rates during the experiment in "Alk" treatment. High redox potential in "Alk" sediments, in comparison with " $\mathrm{SO}_{4}{ }^{2-}+$ Alk" sediments, could promote high sediment mineralization (Ponnamperuma 1984) during the experiment, resulting in lower BOD's at the end of the experiment (Fig. 2). This hypothesis is supported by higher (although not significant) percentage of organic matter in the top layer of "Alk; Medium; and High plant densities" sediments compared to " $\mathrm{SO}_{4}{ }^{2-}+\mathrm{Alk}$; Medium; and High plant densities" (data do not shown). The increase in porewater $\mathrm{CO}_{2}$ concentrations from $0.6 \mathrm{mM}$ in "Control" to $1.5 \mathrm{mM}$ in "Alk" is likely to have caused the areal biomass increase as photosynthesis of isoetids does not saturate until 2-8 mM (Søndergaard and Sand-Jensen 1979; Roelofs et al. 1984; Pedersen et al. 1995). In the present study, however, competition from other plants species was excluded and in the field situation, alkalinization of the water column would likely promote the growth of fastgrowing elodeids that are competitively superior to isoetids (Arts 2002; Lucassen et al. 2009; Spierenburg et al. 2009; 2010; Raun et al. 2010).

The key findings of this study have implications for the conservation and management of softwater lakes with populations of isoetids. Our results indicate that relict population of L. dortmanna may completely disappear at the time water concentrations of both $\mathrm{SO}_{4}{ }^{2-}$ and alkalinity increase as a result of in-lake processes, seepage of polluted groundwater or runoff from the catchment. This indicates that monitoring of local groundwater and runoff is relatively important compared to monitoring of surface water quality in order to detect possible enrichment already in an early stage of the process.

Acknowledgments We thank Jelle Eygensteyn and Roy Peters for their technical and practical help and Natasha Teakle and Liesbeth Bakker for constructive criticism on earlier versions of the manuscript. The project was funded by The Danish Council for Independent Research Natural Science grant No 645-06-0287 and the Centre for Lake Restoration, a Villum Kann Rasmussen Centre of Excellence.

Open Access This article is distributed under the terms of the Creative Commons Attribution License which permits any use, distribution, and reproduction in any medium, provided the original author(s) and the source are credited.

\section{References}

Andersen FØ, Olsen KR (1994) Nutrient cycling in shallow, oligotrophic Lake Kvie, Denmark.2. Effects of isoetids on the exchange of phosphorus between sediment and water. Hydrobiologia 276:267-276

Andersen T, Pedersen O, Andersen FØ (2005) Nutrient concentrations in a Littorella uniflora community at higher $\mathrm{CO}_{2}$ concentrations and reduced light intensities. Freshw Biol 50:1178-1189

Armstrong J, Afreen-Zobayed F, Armstrong W (1996) Phragmites die-back: sulphide- and acetic acid-induced bud and root death, lignifications, and blockages within aeration and vascular systems. New Phytol 134:601-614

Arts GHP (2002) Deterioration of Atlantic soft water macrophyte communities by acidification, eutrophication and alkalinisation. Aquat Bot 73:373-393

Brandrud TE (2002) Effects of liming on aquatic macrophytes, with emphasis on Scandinavia. Aquat Bot 73:395-404

Brouwer E, Soontiens J, Bobbink R, Roelofs JGM (1999) Sulphate and bicarbonate as key factors in sediment degradation and restoration of Lake Banen. Aquat Conserv-Mar Freshw Ecosyst 9:121-132

Christiansen R, Friis NJS, Søndergaard M (1985) Leaf production and nitrogen and phosphorus tissue content of Littorella uniflora (L) Aschers in relation to nitrogen and phosphorus enrichment of the sediment in oligotrophic Lake Hampen, Denmark. Aquat Bot 23:1-11

Frederiksen MS, Holmer M, Pérez M, Invers O, Ruiz JM, Knudsen BB (2008) Effect of increased sediment sulfide concentrations on the composition of stable sulfur isotopes $\left(\mathrm{d}^{34} \mathrm{~S}\right)$ and sulfur accumulation in the seagrasses Zostera marina and Posidonia oceanica. J Exp Marine Biol Ecol 358:98-109

Fry B, Scalan RS, Winters JK, Parker PL (1982) Sulfur uptake by salt grasses, mangroves, and seagrasses in anaerobic sediments. Geochim et Cosmochimi Acta 46:1121-1124

Geurts JJM, Sarneel JM, Willers BJC, Roelofs JGM, Verhoeven JTA, Lamers LPM (2009) Interacting effects of sulphate pollution, sulphide toxicity and eutrophication on vegetation development in fens: a mesocosm experiment. Environ Pollut 157:2072-2081

Goodman JL, Moore KA, Dennison WC (1995) Photosynthetic responses of eelgrass (Zostera marina L.) to light and sediment sulfide in a shallow barrier island lagoon. Aquat Bot 50:37-47

Grasshoff K, Johannsen H (1972) A new sensitive and direct method for the automatic determination of ammonia in sea water. J du Cons Perm Int pour l'Explor de la Mer 34: 289-294 
Henriksen A (1965) An automatic method for determining lowlevel concentrations of phosphates in fresh and saline waters. Analyst 90:29-34

Holmer M, Bondgaard EJ (2001) Photosynthetic and growth response of eelgrass to low oxygen and high sulfide concentrations during hypoxic events. Aquat Bot 70:29-38

Holmer M, Nielsen RM (2007) Effects of filamentous algal mats on sulfide invasion in eelgrass (Zostera marina). J Exp Marine Biol Ecol 353:245-252

Holmer M, Jensen HS, Christensen KK, Wigand C, Andersen FØ (1998) Sulfate reduction in lake sediments inhabited by the isoetid macrophytes Littorella uniflora and Isoetes lacustris. Aquat Bot 60:307-324

Holmer M, Duarte CM, Marbá N (2003) Sulfur cycling and seagrass (Posidonia oceanica) status in carbonate sediments. Biogeochem 66:223-239

Jensen SI, Kuhl M, Glud RN, Jorgensen LB, Prieme A (2005) Oxic microzones and radial oxygen loss from roots of Zostera marina. Marine Ecol-Prog Ser 293:49-58

Kamphake LJ, Hannah SA, Cohen JM (1967) Automated analysis for nitrate by hydrazine reduction. Water Res 1:205-216

Koch MS, Mendelssohn IA (1989) Sulphide as a soil phytotoxin: differential responses in two marsh species. J Ecol 77:565-578

Kok CJ, Van der Velde G (1991) The influence of selected water quality parameters on the decay rate and exoenzymatic activity of detritus of Nymphaea alba 1 floating leaf blades in laboratory experiments. Oecologia 88:311-316

Krause GH, Weis E (1991) Chlorophyll fluorescence and photosynthesis: the basics. Annu Rev Plant Physiol Plant Mol Biol 42:313-349

Laanbroek HJ (1990) Bacterial cycling of minerals that affect plant growth in waterlogged soils: a review. Aquat Bot 38:109-125

Lucassen ECHET, Spierenburg P, Fraaije RGA, Smolders AJP, Roelofs JGM (2009) Alkalinity generation and sediment $\mathrm{CO}_{2}$ uptake influence establishment of Sparganium angustifolium in softwater lakes. Freshw Biol 54:2300-2314

Madsen TV, Olesen B, Bagger J (2002) Carbon acquisition and carbon dynamics by aquatic isoetids. Aquat Bot 73:351-371

Mascaró O, Oliva S, Pérez M, Romero J (2009) Spatial variability in ecological attributes of the seagrass Cymodocea nodosa. Bot Marina 52:429-438

Mattson MD, Likens GE (1993) Redox reactions of organic matter decomposition in a soft water lake. Biogeochem 19:149-172

Møller CL, Sand-Jensen K (2008) Iron plaques improve the oxygen supply to root meristems of the freshwater plant, Lobelia dortmanna. New Phytol 179:848-856

Møller CL, Sand-Jensen K (2011) High sensitivity of Lobelia dortmanna to sediment oxygen depletion following organic enrichment. New Phytol 190:320-331

Murphy KJ (2002) Plant communities and plant diversity in softwater lakes of northern Europe. Aquat Bot 73: 287-324

Olsen SR, Cole CV, Watanabe FS, Dean LA (1954) Estimation of available phosphorus in soils by extraction with sodium bicarbonate. US Dep. of Agric. Circ 939
Pedersen O, Sand-Jensen K, Revsbech NP (1995) Diel pulses of $\mathrm{O}_{2}$ and $\mathrm{CO}_{2}$ in sandy lake sediments inhabited by Lobelia dortmanna. Ecology 76:1536-1545

Pedersen O, Binzer T, Borum J (2004) Sulphide intrusion in eelgrass (Zostera marina L.). Plant, Cell Environ 27:595-602

Pezeshki SR, Pan SZ, Delaune RD, Patrick WH (1988) Sulfideinduced toxicity: inhibition of carbon assimilation in Spartina alterniflora. Photosynthetica 22:437-442

Ponnamperuma FN (1984) Effects of flooding on soils. In: Kozlowski TTE (ed) Floding and plant growth. Academy Press, Inc., Orlando, pp 9-45

Povidisa K, Delefosse M, Holmer M (2009) The formation of iron plaques on roots and rhizomes of the seagrass $C y$ modocea serrulata (R. Brown) Ascherson with implications for sulphide intrusion. Aquat Bot 90:303-308

Psenner R (1988) Alkalinity generation in a soft-water lake: watershed and in-lake processes. Limnol Oceanogr 33:1463-1475

Pulido C, Borum J (2010) Eelgrass (Zostera marina) tolerance to anoxia. J Exp Marine Biol Ecol 385:8-13

Pulido C, Lucassen ECHET, Pedersen O, Roelofs JGM (2011) Influence of quantity and lability of sediment organic matter on the biomass of two isoetids, Littorella uniflora and Echinodorus repens. Freshw Biol 56:939-951

Raun AL, Borum J, Sand-Jensen K (2010) Influence of sediment organic enrichment and water alkalinity on growth of aquatic isoetid and elodeid plants. Freshw Biol 55:1891-1904

Roelofs JGM (1983) Impact of acidification and eutrophication on macrophyte communities in soft waters in The Netherlands. 1. Field observations. Aquat Bot 17:139-155

Roelofs JGM (1991) Inlet of alkaline river water into peaty lowlands: effects on water quality and Stratiotes aloides 1 stands. Aquat Bot 39:267-293

Roelofs JGM, Schuurkes JAAR, Smits AJM (1984) Impact of acidification and eutrophication on macrophyte communities in soft waters. 2. Experimental studies. Aquat Bot 18:389-411

Roelofs JGM, Brandrud TE, Smolders AJP (1994) Massive expansion of Juncus bulbosus L after liming of acidified SW Norwegian Lakes. Aquat Bot 48:187-202

Sand-Jensen K, Prahl C, Stokholm H (1982) Oxygen release from roots of submerged aquatic macrophytes. Oikos 38:349-354

Sand-Jensen K, Borum J, Binzer T (2005a) Oxygen stress and reduced growth of Lobelia dortmanna in sandy lake sediments subject to organic enrichment. Freshw Biol 50:1034-1048

Sand-Jensen K, Pedersen O, Binzer T, Borum J (2005b) Contrasting oxygen dynamics in the freshwater isoetid Lobelia dortmanna and the marine seagrass Zostera marina. Ann Bot 96:613-623

Scheirer CJ, Ray WS, Hare N (1976) The analysis of ranked data derived from completely randomized factorial designs. Biometrics 32:429-434

Smart RM, Barko JW (1985) Laboratory culture of submersed freshwater macrophytes on natural sediments. Aquat Bot 21:251-263

Smolders AJP, Roelofs JGM (1995) Internal eutrophication, iron limitation and sulfide accumulation due to the inlet of 
river Rhine water in peaty shallow waters in The Netherlands. Arch Hydrobiol 133:349-365

Smolders AJP, Roelofs JGM (1996) The roles of internal iron hydroxide precipitation, sulphide toxicity and oxidizing ability in the survival of Stratiotes aloides roots at different iron concentrations in sediment pore water. New Phytol 133:253-260

Smolders AJP, Lamers LPM, Lucassen ECHET, Van der Velde G, Roelofs JGM (2006) Internal eutrophication: how it works and what to do about it-a review. Chem Ecol 22:93-111

Søndergaard M, Sand-Jensen K (1979) Carbon uptake by leaves and roots of Littorella uniflora (L) Aschers. Aquat Bot 6:1-12

Sorrell BK (2004) Regulation of root anaerobiosis and carbon translocation by light and root aeration in Isoetes alpinus. Plant, Cell Environ 27:1102-1111

Spierenburg P, Lucassen ECHET, Lotter AF, Roelofs JGM (2009) Could rising aquatic carbon dioxide concentrations favour the invasion of elodeids in isoetid-dominated softwater lakes? Freshw Biol 54(9):1819-1831
Spierenburg P, Lucassen ECHET, Lotter AF, Roelofs JGM (2010) Competition between isoetids and invading elodeids at different concentrations of aquatic carbon dioxide. Freshw Biol 55:1274-1287

Tessenow U, Baynes Y (1978) Redox-chemical effects of Isoetes Lacustris 1 in littoral sediment of Lake Feldsee (Black Forest). Arch Hydrobiol 82:20-48

Traaen TS (1980) Effects of acidity on decomposition of organic matter in aquatic environments. In: Drablos D, Tollan A (eds) In: Ecological impact of acid precipitation, Proceedings of an international symposium, Sandeflord, Norway, pp 340-341

van Gemerden H (1984) The sulfide affinity of phototrophic bacteria in relation to the location of elemental sulfur. Arch Microbiol 139:289-294

Wium-Andersen S, Andersen JM (1972) Influence of vegetation on redox profile of sediment of Grane Langs $\varnothing$, a Danish lobelia lake. Limnol Oceanogr 17:948-952 